\title{
SOCIO-PHILOSOPHICAL ANALYSIS ON THE TASK OF BIOSPHERA AND HUMAN UNITY
}

\author{
Abdumalikov Abdulatif Abidjanovich \\ PhD, head teacher, Ferghana State University \\ Abdumalikova Erkinoy Anvarovna \\ Teacher of Informatics at school number 14 of the district, Ferghana region of the Republic of \\ Uzbekistan
}

Article DOI: https://doi.org/10.36713/epra2048

\begin{abstract}
Today, continuing and evolving human society strives to absorb the whole globe for its own needs, and as a result, it causes to the natural processes of the globe, the processes of the natural self-renewal of the globe and natural development and restoration of the earth. As a result, the biosphere process has to relinquish its place to the nonatmosphere, a form of human development that is the product of human thinking. This is a process that can have devastating consequences for nature. Nowadays, these and similar problems are the most urgent for all mankind
\end{abstract}

KEW WORDS: biosphere, harmony of nature and society, nature and human thinking, global problems, noosphere.

\section{MATERIALS AND METHODS}

There were used scientific-philosophical principles such as systematics, deductive conclusions, analysis and synthesis, historical and logic, hermeneutic analysis, inheritance, universalism and national identity, comparative analysis during the research.

\section{INTRODUCTION}

There are a great number of scientists in biosciences, who study the biosphere and human issues in their philosophy, in their works, in their teachings, to clarify the relationship to the biosphere, to study humanity in environmental culture, to preserve nature, to appreciate it, and to call for a conscious relationship to take care of it for future generations.

After the Republic of Uzbekistan gained independence, the Aral Sea, a global environmental problem for the region, has been addressed with numerous conferences and calls to solve this problem. And it is unforgettable that, there are also the roles of philosophers.

\section{RESULTS AND DISCUSSION}

The biosphere is the only place where people have the necessary living conditions. The biosphere cannot be replaced by the law: the biosphere cannot be replaced by an artificial environment, as new species cannot be created. Man cannot make an eternal engine, and the biosphere is, in fact, an eternal engine

Every day, the life of a growing population depends directly on the natural resources available in the biosphere. Human Biosphere is a necessary stage of development. Consequently, one can speak about the biosphere function of mankind and the environmental responsibility of society. On this basis, the formation of environmental ethics based on the quality of human life: "Transition to ecological development only means that the increase in the relative free energy of the nonatmosphere is due to the increase in the free energy accumulated in the human being." It is impossible to improve the quality of human beings without the culture that has developed as a result of the ecological development of animals. Environmental development is determined by the activities of the community of people who produce spiritual blessings. This is, of course, not due to extensive but intensive material production. The 
growth of material wealth is non ecological and contributes to environmental disaster on a global scale. The development of the non-sphere depends on the material wealth and the free energy accumulated in man. This means that the future of mankind is inextricably linked to the intellectual, informative and spiritual development of the individual. Therefore, in the context of intensive development of material production, the priority of science and culture is to prioritize. Concepts of "Natural laws".

In this regard, the French philosopher and economist A.Turgo (1727-1728) described the so-called "soil fertility decline", exploring the possibility of intensifying agriculture, which is a particular solution to this problem. The implication is that each hostile labor and capital spent on the cultivated land will have a lower carbon footprint than the earlier spent labor and capital, and once it has reached a certain threshold, it will be ineffective.

Later, the English economist T.R. Maltus (1766-1834) developed these ideas and later promoted a broader concept. According to this concept, there is a "natural law" that regulates the population in terms of its food availability. According to this law, the number of people on the planet increases with geometric progression, and the supply of livelihoods only grows with arithmetic progress, which inevitably causes excessive populations and can cause social tensions. Malthus notes that social development is strictly subject to the rule of eternal laws of nature. She believes that every newborn baby is born into a world that is occupied by others and has no place in it. It also concludes that sympathy for the poorer poor leads to aggravation of already complex demographic problems [2].

Malthus's conclusions as to natural factors that prevent starvation, epidemics, and wars overpopulation have found not only his supporters but also his opponents.

The followers of the Malthus ideals escaped the extreme cold conclusions of their predecessors and continued its doctrine in the context of the demographic explosion of the early 20th century.

As scientists study different trends and trends in geographical school, they usually record mechanical geographical determinism, which seeks to prove that human activity is completely dependent on the natural environment. The founder and famous representative of this stream is the French enlightenment philosopher Sh.L.Monteske (1689-1755). In his work, The Spirit of the Law, he detailed his concept. According to this doctrine, people's lives, their morals, their laws, their habits, and even their political system, depend on the geographical environment and climate in which they live. The thinker recognizes that nature creates humans from birth, and then differentiates them from the point of geographical determinism.

Monteske even uses this approach in his analysis of continental social systems. It compares the lives of the peoples of Asia and Europe, in particular. In his opinion, Asia has no moderate region, so the countries with very cold climates on the continent are in direct contact with the countries with very hot temperatures. In Europe, by contrast, the temperate region is much wider, where the climate gradually cools from south to north. Since each country is similar to its neighbor by its climatic features, no significant differences are observed between them. Monteske concludes that, is why freedom in Asia will never grow, and in Europe it will grow or decrease depending on conditions.

His ideas and conclusions about how the social life of people are closely linked to natural conditions have not only been further developed, but have also been criticized in terms of the geographical indeterminism that denies causation in the interplay of nature and society.

Another approach to extreme of geographical determinism relates primarily to Marxism theory, where the level and direction of social development is primarily determined by the level of development of material production. In this context, nature is involved in human history, because in the process of production man changes not only him but himself. Ultimately, the complexity of social relationships that make a person's essence changes up. From this it is concluded that both the formation of individual traits and the development of society depend primarily on material production rather than geographical environment, and only when analyzing the historically changing nature of human production can we say that certain natural conditions affect certain social processes. At the same time, human beings have always been active in the interplay of nature and society. Consequently, the nature of the environment is not the nature of the social environment, but rather the nature of the social environment.

In this sense, people regulate their metabolism with nature, take it under their general control, and thus blind nature's powers try to control them.

The noted contradiction of the above points is the well-known geographical determinism of the English historian G.T.Bock (1821-1862) in his twovolume work "The History of British Civilization" explaining the backwardness of colonial peoples with their unique climate and nature. It was even more exaggerated in the second half of the nineteenth century when it concluded that the inequality was natural. Natural conditions are the most important factor in the 
development of states in the world history, and the state itself is considered as a biological organism formed by the influence of various geographical factors on the population. From this, Chellen concludes that the struggle of a state for a living space is no more than the law of any living organism - the natural law of the struggle for survival. In his view, this is the basis of the fact that the "living states" of the narrow space, following a strict political imperative, seek to expand their territory by occupation and colonization.

The ideas of geographical determinism are still being actively used today to explain the enormous difference between the "advanced industrial North" and the "backward agrarian South", at the level of socioeconomic development between economically developed and developing countries.

Social ecology, as a field of scientific and philosophical knowledge, has emerged only recently from the late 60 s to mid- $80 \mathrm{~s}$. But this does not mean that environmental problems are just the latest events. There is no doubt that they existed in the past, but that there is insufficient information about the early stages of the biosphere's development makes it hypothetical.

Scientists who study numerous small globular balls found in some parts of the globe, think that they may be melted matter. About 65 million years ago, it is believed that the Earth's surface collided with a giant meteorite, several kilometers in diameter. As a result of this collision, heavy fires started, the smoke emanating from the earth surrounded the thick curtains, causing severe frost and the extinction of the dinosaurs of that time.

Ancient sources indicate that there are still pure environmental factors at the root of existing civilizations. In particular, the Sumerian civilization at the end of the third millennium, the sun was affected by severe drought as a result of changes in activity. The desertification of the once prosperous Tigris and Frot oasis is the result of soil erosion and salinization as a result of erratic irrigated farming.

The realization of this priority is largely determined by human behavior. And human behavior is related to his thinking and thinking. It is human thinking that is at the heart of humanity's hope for the future. In this regard, E. Hart says: "We are approaching a third partner in thinking, a new agent of evolution that has its own evolutionary laws that differ from the laws of genetic and cultural evolution, to the depths of the" gene-think-culture "triangle. Human thinking is the most powerful means of defining human destiny".

The hidden potential under the "gene-culturechains" chain hopes to solve the most difficult environmental problems that threaten to preserve the biosphere through hereditary engineering techniques. Man, using rockets, satellites, orbital stations and other spacecraft, goes beyond the limits of the naturally formed biosphere, but as part of that biosphere, it expands the boundaries of the biosphere - its new quality. At the same time, society begins to interact with nature and enters the biosphere, enriching it with new content. The biosphere is increasingly attracted to the social sphere, and its unrestricted development and improvement impacts the social sphere. At the same time, being a part of nature cannot stop this process. On the contrary, it would mean that a person ceases to be a social being and, consequently, a human being.

Thus, the transfer of the biosphere to the nonatmosphere means first of all that a person must be fully responsible for the evolution of the biosphere as well as itself, without violating the principle of "do no harm" in its transformative activities. There is no clear boundary between the human being as a part of the universe, the product of the social environment and relationships, their nature and essence as their creator, because man has always been the mystery of the universe and its mysteries. However, in science it is accepted to study the complex of human abilities and attributes by its nature. Integrity, communication and social ability are key features of a person.

When it comes to human ecology, it is important to consider the real habits of human populations. Not only the physicality of a person, the material environment in which he lives, but also his spirituality. However, in order to give life to the spirit, the body also needs to live. The overlap of the spirit and the body, while at the same time denying each other, as opposed to each new and new power, requires finding a solution only through something else that is both spiritual and physical. In this sense, the problem of selfrealization, understanding and safeguarding interdependence has always been a major problem for human ecology. "The most important thing in the world is to keep the gap," wrote Monten.

In modern science, the term 'ecosophy' is used in this regard. Ecosophy is a new term that refers to a set of personal values that presuppose the character of the individual, and thus the world outlook.

The category of ecosophy includes the imperative of self-realization and continuous learning, in addition to the system of values. Its most reflexive form can be curated by I. Kant's famous questions: "What is man? What can I know? 'What can I hope for? What should I do? These are universal questions included in the list of universal issues. But in the course of life, certain questions may be raised, depending on the situation. Mental and ethnic characteristics are of paramount importance here. 
Mentality describes the "spirit of time," which forces the individual to think, feel, and most importantly, to act in a certain way. The mechanisms of mental influence are far more complex. The human body absorbs such a feature of the perception of the world along with mother's milk that in the initial socialization process, it lays out its own unique ways of engaging in public life, which can manifest itself in the most disadvantaged situations.

In order to solve this task it is necessary to have a deep knowledge of society and the system of "nature-nature". In fact, this knowledge is the content of philosophy, as well as all the natural, social and technical disciplines. The philosophy of the axiological aspect of philosophy - the ability to define values and moral ideals, to describe moral principles and principles, comes to the fore.

At present, the focus of experts is on the development of eco- dynamics in global, regional and local scales. The situation on the world stage is very important for us because it is closely connected with the sustainable development of humanity. In recent decades, economic development has been characterized by the continuation and intensification of the processes of liberalization and globalization in the economy. At the same time, great attention is paid to the principles of effective environmental policy, since without sustainable development it is impossible to solve environmental problems.

In today's world, environmental taxes and measures to prevent environmental pollution, as well as environmental legislation, are an important tool in environmental policy [3]. Experts' assessment of the dynamics of some elements of ecology in the world suggests that: 1) a small proportion of the world's population lives in water-scarce areas 2) deterioration of arable land resources; 3) By 1950, the global energy consumption has quadrupled and exacerbated the adverse environmental impacts; And 4) serious threats to biodiversity [4].

A number of new publications highlighting the new problems include a study by American scientist $R$. Carson, published in 1962, entitled "The Spring Without Fear" on the negative effects of pesticides and herbicides. It discusses US environmental degradation and the harmful effects of agricultural chemicals on human health. Pollution has begun to cause concern in the West. Most researchers have begun to find meaning in reviving the mystical unity that is characteristic of animistic religions, particularly the Shark religiousphilosophical systems.

\section{CONCLUSION}

Philosophical understanding of human essence has a great educational value. Human philosophy helps to better understand human essence, its importance and importance in every new historical period.

There is no clear boundary between the human being as a constituent of the universe, the product of the social environment and relationships, the nature and essence of their creator, because man has always been a mystery of the universe and its mystery. However, despite this, science has adopted a set of human abilities and attributes that are closely related to its nature. The ability to act wisely, to communicate, and to live a social life are the main characteristics of a person.

Achievement of harmony of the tasks of building a free and prosperous society in Uzbekistan through the acquisition of modern knowledge and high human qualities is the main task of the whole educational work.

Such values as spirituality, morality and education play an important role in the formation of a perfect person. It is these values that make human noble human qualities.

\section{REFERENCES}

1. Golubev V. Man in the biosphere: a time of controlled development // World of Science, 1993. No.2. -16 .

2. Malthus T.R. Experience on the law of population. SPb., 1868.V. 1. - P.469.

3. Weizsacker E., Lovins E.B., Lovins L.Kh. Factor "chegfe". Twice as much wealth from half! resources // A new post-industrial wave in the West. - M., 1999. 1999. No. 1. - 5-6.

4. Kondratyev K.Ya. Ecodynamics and geopolitics: from global to local scales // Ecology. 